\title{
Assessment of Precipitation Trends in the Sertão Paraibano Mesoregion
}

\author{
Susane Eterna Leite Medeiros ${ }^{1}$, Raphael Abrahão ${ }^{1}$ iD, Iker García-Garizábal ${ }^{2}$, \\ Idmon Melo B.M. Peixoto ${ }^{1}$, Louise Pereira da Silva ${ }^{1}$ \\ ${ }^{1}$ Departamento de Engenharia de Energias Renováveis, Centro de Energias Alternativas \\ e Renováveis, Universidade Federal da Paraíba, João Pessoa, PB, Brazil. \\ ${ }^{2}$ Faculty of Engineering in Earth Sciences, Escuela Superior Politécnica del Litoral, \\ Campus Gustavo Galindo, Guayaquil, Ecuador.
}

Received: December 4, 2017 - Accepted: January 19, 2018

\begin{abstract}
The state of Paraiba, located in the northeastern region of Brazil, comprises 223 municipalities and covers an area of $56,469 \mathrm{~km}^{2}$. Paraíba is divided into four major mesoregions: Zona da Mata, Agreste, Borborema and Sertão Paraibano. For this study, the Sertão Paraibano mesoregion, a semiarid area, was chosen to understand vulnerability to climate change, taking into account the region's economic importance for water and energy supply. The Mann-Kendall non-parametric test was applied to evaluate trends in the historical series of monthly, trimestrial, biannual and annual precipitation data. The series utilized corresponded to the period 1912-2012 and were built from data generated by five meteorological stations distributed throughout the mesoregion. These stations are maintained by the Executive Agency for Water Management (AESA) and National Department of Works Against Drought (DNOCS). The results indicated increasing precipitation trends for the Sertão Paraibano mesoregion, especially in the annual evaluation, for the first semester of the year (January to June), for the trimester December-January-February and the month of January, with slopes between $2.67 \mathrm{~mm} /$ year and $5.45 \mathrm{~mm} /$ year. The results evidenced the need to deepen studies on the influence of climate change in the area, to promote prompt adaptation measures.
\end{abstract}

Keywords: precipitation, climate change, trend analysis, Mann-Kendall test, semiarid, Brazil.

\section{Avaliação de Tendências de Precipitação na Mesorregião do Sertão Paraibano}

\begin{abstract}
Resumo
O estado da Paraíba, localizado na região Nordeste do Brasil, possui 223 municípios, distribuídos numa área de 56.469 $\mathrm{km}^{2}$. A Paraíba é dividida em quatro mesorregiões: Zona da Mata, Agreste, Borborema e Sertão Paraibano. Para este estudo, a mesorregião semiárida, Sertão Paraibano, foi escolhida, a fim de compreender a vulnerabilidade às alterações climáticas, considerando sua importância econômica para fornecimento de água e energia. O teste não-paramétrico Mann-Kendall foi utilizado com a finalidade de avaliar tendências nas séries históricas de dados de precipitação mensal, trimestral, semestral e anual. As séries utilizadas correspondem ao período de 1912-2012, construídas a partir de dados provenientes de cinco estações meteorológicas, distribuídas pela mesorregião, mantidas pela Agência Executiva de Gestão das Águas (AESA) e Departamento Nacional de Obras Contra a Seca (DNOCS). Os resultados indicam tendência de aumento na precipitação, principalmente nos intervalos de tempo anual, no primeiro semestre de janeiro a junho (J-J), no trimestre dezembro, janeiro e fevereiro (DJF) e no mês de Janeiro, com incrementos anuais entre 2,67 $\mathrm{mm} /$ ano e 5,45 mm/ano. Os resultados evidenciam a necessidade de aprofundar estudos sobre influência das mudanças climáticas na mesorregião do Sertão Paraibano, com o intuito de mitigar os seus efeitos ou promover medidas de adaptação.
\end{abstract}

Palavras-chave: precipitação, mudança climática, análise de tendências, teste de Mann-Kendall, semiárido, Brasil.

Corresponding author: Raphael Abrahão, raphael@cear.ufpb.br. 


\section{Introduction}

Climate change can be defined as a set of statistical variations in the mean state of climate or its variability, attributed directly or indirectly to human activity or to natural causes as well. These variations persist for long periods of time and can be detected and assessed through historical series of meteorological data (IPCC, 2007). Furthermore, it is understood that climate trends are characterized by a soft or monotonous change (increase or decrease) in the mean values of these series. The occurrence of climate changes for a specific region can be confirmed by time series trends (Blain, 2010).

Among the topics of climate change, some works can be mentioned that approach trend analysis for meteorological variables in different locations, such as Groisman and Easterling (1993), Easterling et al. (1997), Karl and Knight (1998), Kheshgi and White (2001), Easterling (2002), Matsuyama et al. (2002), Modarres and Silva (2007), Fu et al. (2013). For Brazil, the study of Salviano et al. (2016) analyzed trends in precipitation and temperature data for the entire country. Awange et al. (2016) studied droughts in Brazil over a period of more than 100 years. Moraes et al. (1998), Marengo and Camargo (2008) and Pinheiro et al. (2013) evaluated trends for the South region of Brazil, while Marengo (2003) and Santos and Lucio (2015) studied climatic trends in the North region. Ramos (1975), Silva (2004), Moscati and Gan (2007), Oliveira and Lima (2014) and Costa et al. (2015) studied the dynamics, distribution and trend for precipitation in the Northeast region and Folhes and Fisch (2006), Minuzzi et al. (2007) and Blain $(2009,2010,2012)$ focused on the Southeast region, specially the São Paulo state.

Lucena et al. (2009), based on long-term climate projections for the A2 and B2 IPCC emission scenarios, indicated that climate change will affect natural resources related to renewable energy, and predicted increases in vulnerability for all energy sectors in Brazil, especially in the Northeast region, where the worst climatic scenarios are foreseen, with substantial increases in temperature and drought. Changes in precipitation and temperature patterns can cause or accentuate water quantity and quality problems in the region as well (Benito, 2013).

The state of Paraiba is part of the Northeastern region of Brazil and presents semiarid climate in most of its territory, with consequent water scarcity and social issues (Pedroza, 2009). The Coremas-Mãe D'água dam complex is located in the semiarid region, belonging to the Piranhas river basin. The Coremas-Mãe D'água dam complex stands out for storing a total of 1,358 billion $\mathrm{m}^{3}$ of water, thus composing the greatest water storage potential of the Sertão Paraibano mesoregion (AESA, 2009a). Since 1957, the area has a small hydroelectric power plant, which is supplied from the Estevam Marinho and Mãe D'água reservoirs, supplied by the Piancó and Aguiar rivers. The hydroelectric power plant has two generating units, $1,760 \mathrm{~kW}$ each, totalling 3,520 kW (CHESF, 2016). Due to the importance of this region to the water and energy supplies of the State of Paraiba, and the potential impact of changes in the availability of water resources, the present study aims to verify the existence (and understand the behavior) of possible precipitation trends in the area of the Coremas-Mãe D'água dam complex in the Sertão Paraibano mesoregion.

\section{Material and Methods}

\subsection{Characterization of the study area, identification of meteorological stations and organization of data}

The state of Paraiba is located in the northeastern region of Brazil. The state presents three types of climate: humid coastal, tropical and semiarid (IBGE, 2002), with a very variable annual regime of precipitations, ranging from $300 \mathrm{~mm}$ to 2,000 $\mathrm{mm}$ (Cavalcanti, 2009). The state is geographically divided in four mesoregions: Zona da Mata, Agreste, Borborema and Sertão Paraibano (AESA, 2009b); the latter is the main semiarid area and corresponds to the study area chosen for this study (Fig. 1).

The Sertão Paraibano mesoregion presents a semiarid tropical climate characterized by dry landscapes and high temperatures, accompanied by low annual thermal variability and high rainfall irregularities. In addition, the region is marked by long periods of drought (Cavalcanti et al., 2009; Mendonça and Danni-Oliveira, 2007).

Time series with rainfall information were obtained from 1912 to 2012, to verify rainfall variability and trend analysis. Data were provided by the monitoring networks of the Executive Agency for Water Management (AESA) and National Department of Works Against Drought (DNOCS).

The pluviometric monitoring network of the state of Paraiba is standardized according to criteria from the World Meteorological Organization and presents 265 stations equipped with Ville de Paris rain gauges (Becker et al., 2011). For this study, five meteorological stations were considered, out of the more than 40 that exist in the mesoregion of Sertão Paraibano, selected due to their proximity to the Coremas-Mãe D'água dams complex and data quality (more years available with less interruptions or data problems in the series). Pluviometric information was organized in discrete time series, following criteria of identification and evaluation of atypical values (outliers), in such a way that all analyzed years contain all months (January to December), without interruptions (Table 1). Therefore, for the construction of the series, the only years used were those containing complete precipitation data from January to December, without exception. Incomplete years were excluded from the series and represented between $2 \%$ and $17 \%$ of the stations series (Table 1 ). 


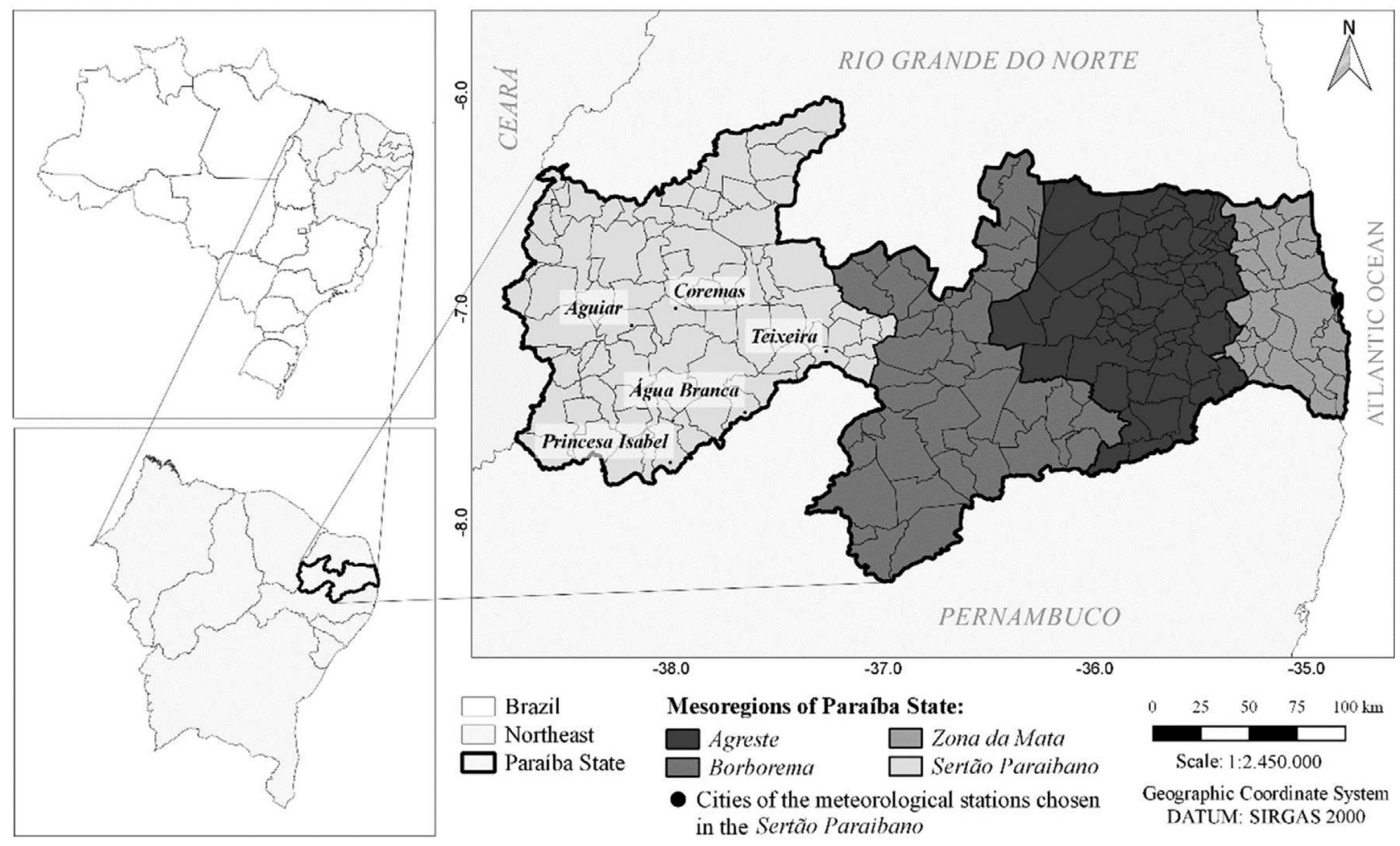

Figure 1 - Geographic locations of the mesoregions of the State of Paraiba and identification of the municipalities with the five meteorological stations studied (Adapted from AESA, 2009b).

Table 1 - Meteorological stations used in the study.

\begin{tabular}{|c|c|c|c|c|c|c|c|}
\hline Station number & Operator & Station & Range of series (year) & Lat. $\mathrm{S}\left({ }^{\circ}\right)$ & Lon. W $\left(^{\circ}\right)$ & Number of absent years & Period (years) \\
\hline \multirow[t]{2}{*}{737022} & AESA & Água Branca & $1936-2012$ & -7.51 & -37.62 & 4 & 72 \\
\hline & AESA & & & -7.51 & -37.64 & & \\
\hline \multirow[t]{2}{*}{738025} & DNOCS & Aguiar & $1935-2012$ & -7.08 & -38.18 & 6 & 71 \\
\hline & AESA & & & -7.09 & -38.17 & & \\
\hline \multirow[t]{2}{*}{737019} & DNOCS & Coremas & $1934-2012$ & -7.02 & -37.97 & 13 & 65 \\
\hline & AESA & & & -7.03 & -37.94 & & \\
\hline \multirow[t]{2}{*}{738013} & DNOCS & $\begin{array}{c}\text { Princesa } \\
\text { Isabel }\end{array}$ & $1912-2012$ & -7.73 & -38.02 & 2 & 98 \\
\hline & AESA & & & -7.73 & -37.99 & & \\
\hline \multirow[t]{2}{*}{737002} & DNOCS & Teixeira & $1926-2011$ & -7.22 & -37.27 & 7 & 78 \\
\hline & AESA & & & -7.22 & -37.25 & & \\
\hline
\end{tabular}

\subsection{Statistical methods for the trend analysis}

The linear regression method and the non-parametric Mann-Kendall statistical test were applied according to the methodology proposed by Sneyers (1992) to describe the behavior of time series and verify the existence of trends.

The Mann-Kendall test is usually employed to understand trends in time series of climate data. One of the main advantages of non-parametric tests is that application is independent of data distribution. A limitation of these tests lies in the need for interdependence between the elements of the series, that is, sequence of data must occur independently and randomly, characterizing a simple random series whose distribution of probability is homogeneous (Goossens and Berger, 1986; Back, 2001; Fechine and Galvíncio, 2010).

The Future Climate and Hydrological Scenarios for Environmental Management and Assessment program (FuCHSIA) was applied to assess rainfall trends for the monthly, trimestrial (December-January-February: DJF, March-April-May: MAM, June-July-August: JJA, September-October-November: SON), biannual (January to June: 
J-J and July to December: J-D), and annual precipitation data. FuCHSIA was developed to analyze time-series trends in scenarios of current climate and conditions of climate change (García-Garizábal and Espinoza, 2016; García-Garizábal et al., 2017). The program was developed by the private sector and more details and information may be obtained in García-Garizábal et al. (2017). The FuCHSIA program applies the Mann-Kendall test to identify trends in time series and uses the Sen's linear regression method as a quantifier to define the slope of the line and provide the magnitude of the trend (Mann, 1945; Sen, 1968; Kendall, 1975).

\section{Results and Discussion}

The mean annual precipitation in the area varied between $715.59 \mathrm{~mm}$ (Teixeira station) and $879.11 \mathrm{~mm}$ (Coremas station). The monthly distribution of precipitation presents similar behavior across the five stations (Fig. 2), with maximum values for February, March and April, and minimum values for August, September and October, evidencing when wet and dry periods occur, which are a common characteristic of this area of the Brazilian semiarid.

The intra-annual variability of precipitation in the mesoregion is accentuated. The maximum values of the monthly mean rainfall occur in March for the five stations studied. The minimum values occur in August for the Teixeira station, in September for three of the five stations (Aguiar, Coremas and Princesa Isabel stations) and in October for the station in Água Branca. Significant increases in precipitation were detected for the annual, biannual, trimestrial and monthly trends, but with different magnitudes and error probabilities across stations (Table 2). All stations presented positive values with significant trends between $2.67 \mathrm{~mm} /$ year and $5.45 \mathrm{~mm} /$ year for the total annual precipitation, except for Princesa Isabel.

In the biannual intervals, for J-J all trends were significantly positive, between $3.10 \mathrm{~mm} /$ year and $3.97 \mathrm{~mm} /$ year, indicating precipitation increases in the area. The only ex-

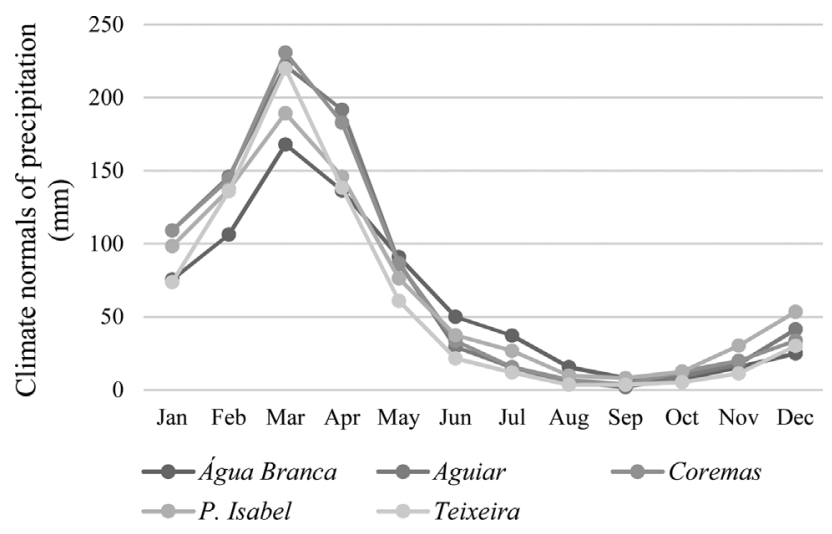

Figure 2 - Monthly climate normals of precipitation for the five stations studied (data from 1912 to 2012). ception was, again, the Princesa Isabel station. In the period J-D, only two stations presented significant trends, which ranged from $0.71 \mathrm{~mm} /$ year for Teixeira station and $1.23 \mathrm{~mm} /$ year for Água Branca station. In addition, the slopes in the J-J period were always higher than J-D slopes (Table 2).

Regarding trimestrial analysis, significant trends were detected, with increased precipitation during DJF for four of the five meteorological stations, with values between $1.65 \mathrm{~mm} /$ year and $2.44 \mathrm{~mm} /$ year. In MAM, the Princesa Isabel station registered the only significant trend (increase of $1.10 \mathrm{~mm} / \mathrm{year}$ ). In JJA, the results indicated a significant increase trend of $0.59 \mathrm{~mm} / \mathrm{year}$ and $1.00 \mathrm{~mm} / \mathrm{year}$ for Teixeira and Água Branca stations, respectively. In SON, the only station that presented a significant trend was Teixeira, with an increase of $0.06 \mathrm{~mm} /$ year. In addition, $25 \%$ of slope values were negative, with no statistical significance.

For the monthly assessments, although the month with highest precipitation in the mesoregion is March, the month of January was the most affected of all, presenting values of significant trends between $0.58 \mathrm{~mm} / \mathrm{year}$ and $0.88 \mathrm{~mm} /$ year in four of the five meteorological stations. In the same way, the Água Branca station presented the highest number of months affected by significant trends, between $0.09 \mathrm{~mm} /$ year in December and $0.88 \mathrm{~mm} /$ year in January. There was a predominance of positive trend values, and $33.3 \%$ presented statistical significance.

The results highlight that the annual cumulative values of precipitation presented stronger significant trends compared to some isolated periods of the year (i.e. biannual, trimestrial or monthly). This is due to the characteristics of trend tests, where greater variability in data decreases the determination of significant trends.

Four of the five meteorological stations showed significant increases in precipitation for the annual period, first semester (J-J), first quarter (DJF) and January. The meteorological stations Água Branca and Teixeira presented significant increasing trends for precipitation in higher number of periods. The stations Coremas and Aguiar presented similar behavior, with significant trends in the same periods, and the station in Princesa Isabel was the most different, showing significant increasing trends in only $10.5 \%$ of its series (in trimester MAM and the month July).

The differentiated behavior at Princesa Isabel station probably occurred due to the climatic factors influencing the flow of heat and humidity locally, such as the relief, which plays an important role as regulator of humidity and temperature by altitude (Princesa Isabel is at $683 \mathrm{~m}$ of altitude), besides its position, orientation of its slopes and declivity. In addition, rainfall irregularities and high temperatures are characteristic features of the Sertão region (Mendonça; Danni-Oliveira, 2007). Therefore, in order to better understand the singular behavior presented at Prin- 
Table 2 - Precipitation trends (1912-2012) for the meteorological stations Água Branca, Aguiar, Coremas, Princesa Isabel and Teixeira.

\begin{tabular}{|c|c|c|c|c|c|}
\hline \multicolumn{6}{|c|}{ Precipitation trends (mm/year) } \\
\hline Period & Água Branca & Aguiar & Coremas & Princesa Isabel & Teixeira \\
\hline Annual & $5.45 * * *$ & $2.67+$ & $3.43 *$ & $0.61 \mathrm{~ns}$ & $4.70 * *$ \\
\hline J-J & $3.97 * *$ & $3.37+$ & $3.10+$ & $0.92 \mathrm{~ns}$ & $3.61 * *$ \\
\hline $\mathrm{J}-\mathrm{D}$ & $1.23 * * *$ & $-0.19 \mathrm{~ns}$ & $0.18 \mathrm{~ns}$ & $-0.12 \mathrm{~ns}$ & $0.71 * * *$ \\
\hline DJF & $2.44 * * *$ & $1.65 *$ & $1.77 *$ & $-0.24 \mathrm{~ns}$ & $1.93 * *$ \\
\hline MAM & $1.11 \mathrm{~ns}$ & $0.86 \mathrm{~ns}$ & $-0.23 \mathrm{~ns}$ & $1.10+$ & $1.44 \mathrm{~ns}$ \\
\hline JJA & $1.00 * * *$ & $-0.12 \mathrm{~ns}$ & $0.10 \mathrm{~ns}$ & $0.28 \mathrm{~ns}$ & $0.59 * * *$ \\
\hline SON & $0.05 \mathrm{~ns}$ & $-0.07 \mathrm{~ns}$ & $0.00 \mathrm{~ns}$ & $-0.20 \mathrm{~ns}$ & $0.06 *$ \\
\hline January & $0.88 * *$ & $0.80+$ & $0.86 *$ & $0.32 \mathrm{~ns}$ & $0.58 * *$ \\
\hline February & $0.82 *$ & $0.66 \mathrm{~ns}$ & $0.38 \mathrm{~ns}$ & $-0.18 \mathrm{~ns}$ & $0.46 \mathrm{~ns}$ \\
\hline March & $0.17 \mathrm{~ns}$ & $-0.45 \mathrm{~ns}$ & $-0.76 \mathrm{~ns}$ & $0.24 \mathrm{~ns}$ & $0.07 \mathrm{~ns}$ \\
\hline April & $-0.01 \mathrm{~ns}$ & $0.54 \mathrm{~ns}$ & $0.13 \mathrm{~ns}$ & $0.49 \mathrm{~ns}$ & $0.75 \mathrm{~ns}$ \\
\hline May & $0.83 *$ & $0.46 \mathrm{~ns}$ & $0.20 \mathrm{~ns}$ & $0.28 \mathrm{~ns}$ & $0.31 \mathrm{~ns}$ \\
\hline June & $0.33+$ & $-0.08 \mathrm{~ns}$ & $0.00 \mathrm{~ns}$ & $0.01 \mathrm{~ns}$ & $0.14 * * *$ \\
\hline July & $0.30 *$ & $-0.01 \mathrm{~ns}$ & $0.03 \mathrm{~ns}$ & $0.14 *$ & $0.13 * * *$ \\
\hline August & $0.15 * * *$ & $0.00 \mathrm{~ns}$ & $0.00 \mathrm{~ns}$ & $0.00 \mathrm{~ns}$ & $0.00 \mathrm{~ns}$ \\
\hline September & $0.00 \mathrm{~ns}$ & $0.00 \mathrm{~ns}$ & $0.00 \mathrm{~ns}$ & $0.00 \mathrm{~ns}$ & $0.00 \mathrm{~ns}$ \\
\hline October & $0.00 \mathrm{~ns}$ & $0.00 \mathrm{~ns}$ & $0.00 \mathrm{~ns}$ & $0.00 \mathrm{~ns}$ & $0.00 \mathrm{~ns}$ \\
\hline November & $0.00 \mathrm{~ns}$ & $0.00 \mathrm{~ns}$ & $0.00 \mathrm{~ns}$ & $-0.03 \mathrm{~ns}$ & $0.00 \mathrm{~ns}$ \\
\hline December & $0.09 * *$ & $0.00 \mathrm{~ns}$ & $0.06 \mathrm{~ns}$ & $-0.01 \mathrm{~ns}$ & $0.02 \mathrm{~ns}$ \\
\hline
\end{tabular}

ns: not significant; $+\mathrm{p}<0.10 ;{ }^{*} \mathrm{p}<0.05 ;{ }^{*} \mathrm{p}<0.01 ;{ }^{*} \mathrm{p}<0.001$.

cesa Isabel, a more in-depth local study of climatic factors and elements is necessary.

In the stations Água Branca, Aguiar, Coremas and Princesa Isabel, at least one of the intervals (annual, biannual, trimestrial or monthly) presented negative trends, which would indicate a decrease in rainfall. However, none presented statistical significance. Other statistical methods could be applied in conjunction with trend analysis to corroborate the understanding of the dynamics of climate change in the area, like cluster analysis (Abrahão, 2014; Lyra et al., 2014; Teodoro et al., 2016).

The detected trends indicate that, in 10 years, precipitation will be higher when compared to the means observed in 3\% (in Aguiar) and 7\% (in Teixeira and Água Branca), with the highest annual mean in Coremas, above $910 \mathrm{~mm}$, indicating an increase of $4 \%$ in 10 years (Table 3). The ex- pected increases in 30 years for Água Branca and Teixeira are sharper than those of Aguiar and Coremas. While these will increase by $9 \%$ and $12 \%$, respectively, Água Branca may reach an annual mean of almost $900 \mathrm{~mm}$, and Teixeira above $850 \mathrm{~mm}$. In 50 years, Água Branca, Aguiar and Coremas may present annual precipitation means above $1000 \mathrm{~mm}$. Teixeira could increase its annual mean by $33 \%$, reaching more than $950 \mathrm{~mm}$.

From what has been observed by the trends, these future increases will not be uniform throughout the year. At Água Branca station, the highest number of monthly series with significant trends ( 7 in 12 series) were detected. In 10 years, it may rain from $25.8 \mathrm{~mm}$ (in December) to $114.5 \mathrm{~mm}$ (in February). Keeping this perspective in 50 years, the observed trends indicate a possible increase in

Table 3 - Projected annual mean precipitation for 10, 20, 30, 40 and 50 years at stations with significant annual trends detected (Água Branca, Aguiar, Coremas and Teixeira).

\begin{tabular}{lccccccc}
\hline Station & $\begin{array}{c}\text { Precipitation } \\
\text { means }(\mathrm{mm})\end{array}$ & $\begin{array}{c}\text { Precipitation } \\
\text { trends (mm/year) }\end{array}$ & \multicolumn{5}{c}{ Projected annual mean precipitation $(\mathrm{mm})$} \\
\cline { 5 - 8 } & & & 10 years & 20 years & 30 years & 40 years & 50 years \\
\hline Água Branca & 735.31 & 5.45 & 789.81 & 844.31 & 898.81 & 953.31 & 1007.81 \\
Aguiar & 876.02 & 2.67 & 902.72 & 929.42 & 956.12 & 982.82 & 1009.52 \\
Coremas & 879.11 & 3.43 & 913.41 & 947.71 & 982.01 & 1016.31 & 1050.61 \\
Teixeira & 715.59 & 4.70 & 762.59 & 809.59 & 856.59 & 903.59 & 950.59 \\
\hline
\end{tabular}


relation to the mean monthly precipitation between $18 \%$ and 58\%, in December and January respectively.

The future projections reinforce the notion that it is raining more yearly and monthly in the mesoregion of Sertão Paraibano. However, to better understand this climatic dynamics, more detailed studies on the spatial and temporal distribution of precipitation are necessary, as well as the application of robust climate models, along with the observed trends.

The Nucleus of Strategic Affairs of the Brazilian Presidency (NAE, 2005a, b) indicates that Brazilian Northeast is one of the most vulnerable regions to climate change due to climate (mostly semiarid), social and economic factors. Therefore, the Coremas-Mãe D'água dam complex is a key infrastructure for supplying water to population and generating electricity. Thus, studies that include analysis of climate variability in the Paraiba region are necessary to preventively address the issues arising from climate change and its environmental, economic and social impacts. Although the Intergovernmental Panel on Climate Change (IPCC) projections indicated an increase in temperatures throughout the Brazilian territory, precipitation analyses did not present conclusive results (IPCC, 2007), evidencing the need to continue developing pluviometric studies that address the dynamics and evolution of this climate component.

\section{(a) Annual trend for precipitation}

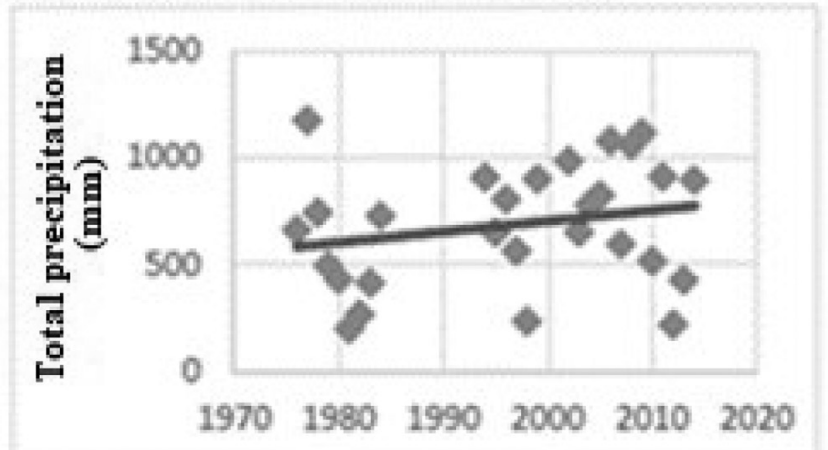

In the present study, trends of increase in the total annual rainfall were observed. These results complement those reported by Peixoto and Abrahão (2015) for the municipalities of Patos and São Gonçalo, which also belong to the mesoregion of Sertão Paraibano. Also, decreases were detected in cloudiness and number of rainy days (Figs. 3 and 4), leading one to believe that rainfall intensity is increasing in the area. The study of Peixoto and Abrahão therefore detected that recent rainfall events were more intense, as a significant decreasing trend was detected for rainy days combined with an increase in total annual rainfall. Other studies based on climate models also suggest a higher probability of increased frequency of consecutive dry days in the Northeast region of Brazil, correlating with desertification processes, especially in the semiarid portion (Conti, 2005; IPCC, 2007; Nobre, 2011; Costa and Soares, 2012).

A study on extreme precipitation events for the semiarid region of the Brazilian Northeast by Costa et al. (2015) indicated an increase in drought intensity, which corroborates the results found by Peixoto and Abrahão (2015). However, Costa et al. (2015) detected decreasing trends for intense precipitation events and reduction of the annual precipitation in the dry and rainy periods. This highlights the lack of uniformity in rainfall distribution for this region as the meteorological stations considered were dif-

\section{(b) Annual trend for number of days with rain}

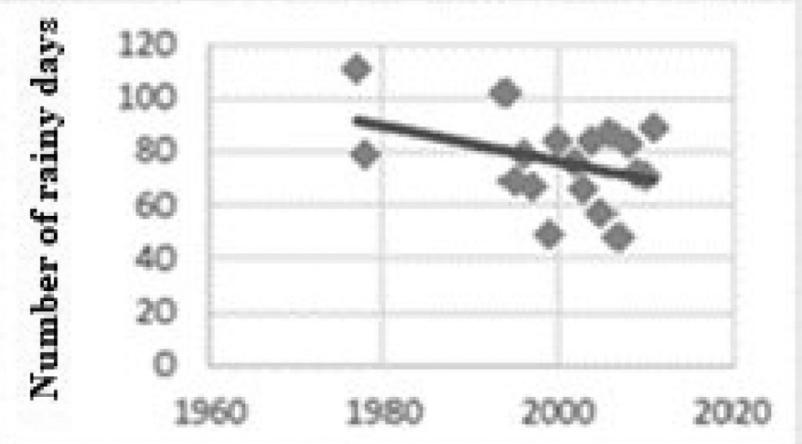

(c) Annual trend for cloudiness

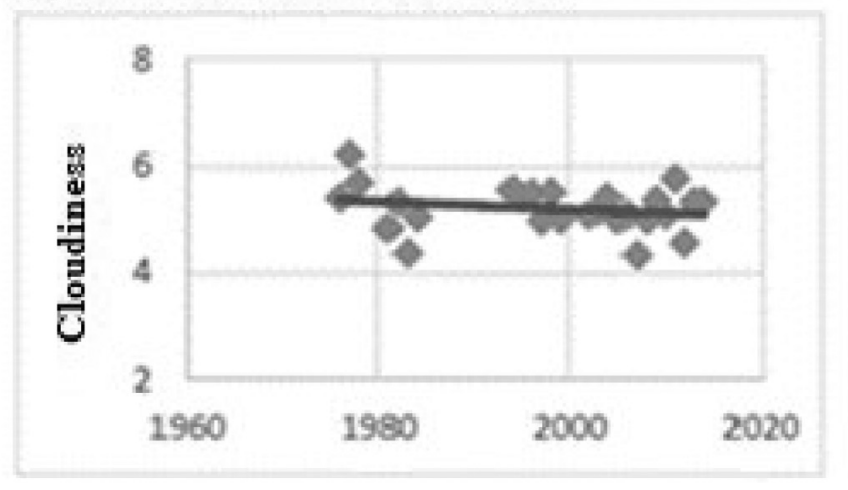

Figure 3 - Annual trends for precipitation (a), number of rainy days (b) and cloudiness (c) for the Patos station in the mesoregion of Sertão Paraibano (Adapted from Peixoto; Abrahão, 2015). 


\section{(a) Annual trend for precipitation}

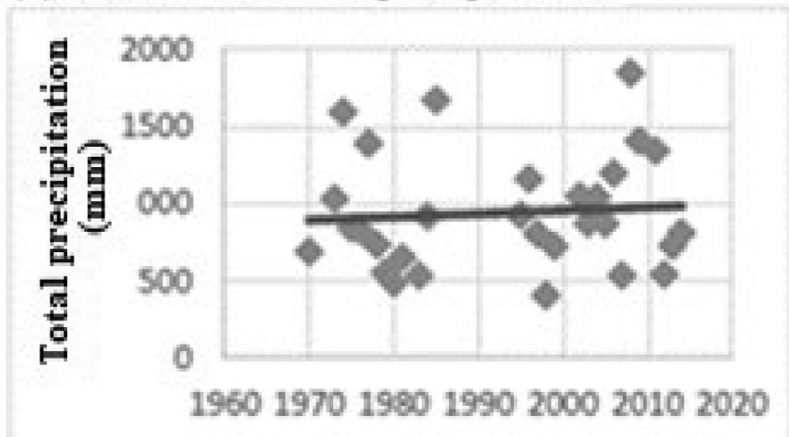

(b) Annual trend for number of days with rain

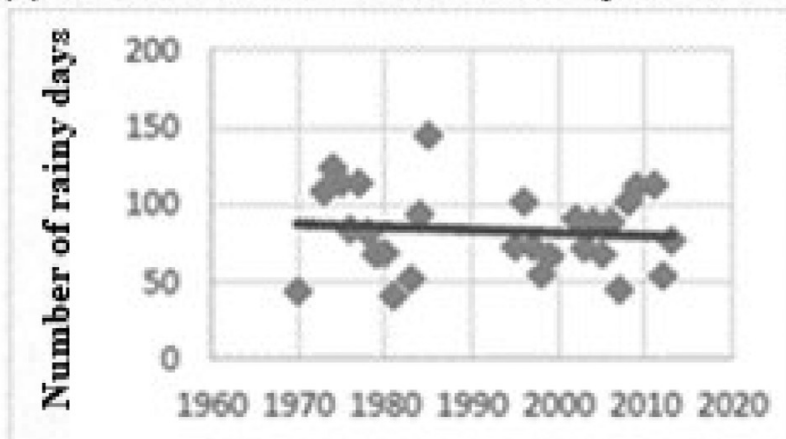

(c) Annual trend for cloudiness

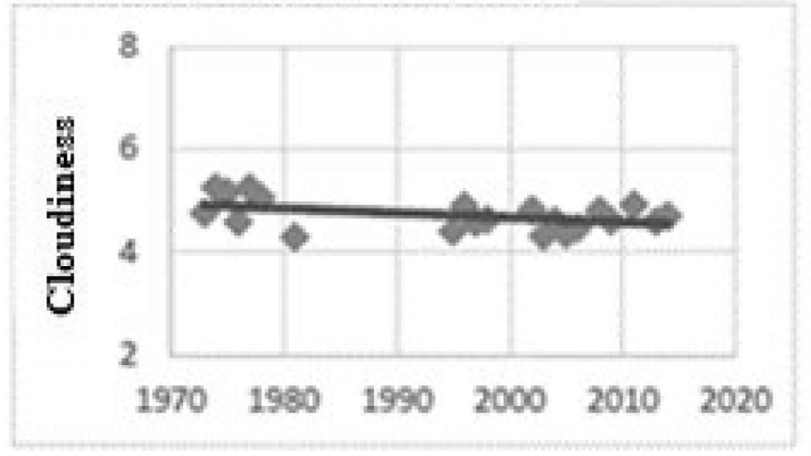

Figure 4 - Annual trends for precipitation (a), number of rainy days (b) and cloudiness (c) for the São Gonçalo station, in the Sertão Paraibano mesoregion (Adapted from Peixoto; Abrahão, 2015).

ferent. The study by Silva et al. (2004) observed high variability for the spatial distribution of precipitation and number of rainy days in Northeast Brazil. Variability is usually higher during the dry period. In addition, the authors affirm that the Northeastern semiarid region presents the highest coefficient of variation for rainfall and number of rainy days when compared to other areas of Brazil.

According to the Brazilian National Water Agency (ANA), during this century most cities with more than 5,000 inhabitants in the semiarid Northeast will face difficulties to supply water for human consumption due to population growth and increased water demands (ANA, 2005). Furthermore, it is important to emphasize that the Brazilian electricity grid is based on renewable sources, with hydroelectric being responsible for more than $60 \%$ of national electricity generation in 2015 (EPE, 2014; Delgado and Carvalho, 2016). However, for the state of Paraiba, electricity generation in hydroelectric power plants represented only $0.7 \%$ of installed capacity although electricity generated by hydroelectric plants in Northeast Brazil represents $49 \%$ of its total electricity generation capacity (EPE, 2014; Nogueira et al., 2014).

Thus, the sustainability of an electricity matrix based on hydropower implies in the need to continue developing studies to better understand the occurrence and distribution of precipitation under climate change influence, to elabo- rate appropriate plans for the management of water and energy resources.

\section{Conclusions}

Trend analysis detected significant positive trends for precipitation in four of the five meteorological stations for the annual time interval in the Sertão Paraibano mesoregion. The trend values obtained in the different stations and analyzed time intervals were heterogeneous, although four of the five stations showed similar behavior in the evolution of precipitation. Trend values for the annual assessment were between $2.67 \mathrm{~mm} /$ year and $5.45 \mathrm{~mm} /$ year; biannual (J-J) were between $3.10 \mathrm{~mm} /$ year and $3.97 \mathrm{~mm} /$ year, trimestrial (DJF) between $1.65 \mathrm{~mm} /$ year and $2.44 \mathrm{~mm} /$ year and monthly (January) between $0.58 \mathrm{~mm} / \mathrm{year}$ and $0.88 \mathrm{~mm} /$ year.

No significant negative trends were observed, which means that, according to the results obtained, it is possible to perceive significant trends only for the increase of precipitation in the mesoregion of Sertão Paraibano.

The work presented herein represents an important contribution for the comprehension of dynamics of climate evolution in the Brazilian semiarid, providing information that can be applied to the development of environmental measures and management of water resources in this vulnerable region. 


\section{Acknowledgments}

This work was carried out with the support of AESA (Executive Agency for Water Management) and CNPq projects 305419/2015-3 and 401687/2016-3.

\section{References}

ABRAHãO, R. Compreensão de mudanças climáticas regionais atraves da aplicação de três métodos estatísticos. In: V Congresso Brasileiro de Energia Solar, 2014.

AESA - Agência Executiva de Gestão das Águas do Estado da Paraíba. Plano Estadual de Recursos Hídricos - Relatório final. João Pessoa, 2009a. Disponível em: http://www.aesa.pb.gov.br/perh/. Acesso em: 25 nov. 2016.

AESA - Agência Executiva de Gestão das Águas do Estado da Paraíba. Mapa das mesorregiões do Estado da Paraíba. João Pessoa, 2009b. Disponível em: http://www.aesa.pb.gov.br/perh/. Acesso em: 25 nov. 2016.

ANA - Agência Nacional das Águas. Caderno de Recursos Hídricos. Disponibilidade e demanda de recursos hídricos no Brasil. 2005. Disponível em: http://www2.ana.gov.br/Paginas/servicos/planejamento/est udos/cadernoderecursos.aspx. Acesso em: 25 nov. 2016.

AWANGE, J.L.; MPELASOKA, F.; GONCALVES, R.M. When every drop counts: Analysis of Droughts in Brazil for the 1901-2013 period. Science of The Total Environment, v. 566, p. 1472-1488, 2016.

BACK, J.A. Aplicação de análise estatística para a identificação de tendências climáticas. Pesquisa Agropecuária Brasileira, v. 36, n. 5, p. 717-726, 2001.

BECKER, C.T.; MELO, M.M.M.S; COSTA, M.N.M.; RIBEIRO, R.E.P. Caracterização Climática das Regiões Pluviometricamente Homogêneas do Estado da Paraíba. Revista Brasileira de Geografia Física, v. 1, p. 286-299, 2011.

BENITO, Y. Energy and Climate Change. Capacity Building Programmed on Renewable Energy. Observatory for Renewable Energy in Latin America and the Caribean. 2013. Disponível em: http://www.renenergyobservatory.org/en/capacity-building-programme.html. Acesso em: 15 jul. 2016.

BLAIN, G.C. Considerações estatísticas relativas à oito séries de precipitação pluvial da Secretaria de Agricultura e Abastecimento do Estado de São Paulo. Revista Brasileira de Meteorologia, v. 24, n. 1, p. 12-23, 2009.

BLAIN, G.C. Tendências e variações climáticas em séries anuais de precipitação pluvial do estado de São Paulo. Bragantia, v. 69 , n. 3 , p. $765-770,2010$.

BLAIN, G.C. Monthly values of the standardized precipitation index in the State of São Paulo, Brazil: trends and spectral features under the normality assumption. Bragantia, v. 71, n. 1, p. 122-131, 2012.

CAVALCANTI, I.F.A.; FERREIRA, N.J.; DIAS, M.A.F.S.; SILVA, M.G.A.J.S. Tempo e clima no Brasil. São Paulo: Oficina de textos, 2009.

CHESF - Companhia Hidroelétrica do São Francisco. Curemas. 2016. Disponível em: https://www.chesf.gov.br/SistemaChesf/Pages/SistemaGer acao/Curemas.aspx. Acesso em: 12 jul. 2016.
CONTI, J.B.A questão climática do nordeste brasileiro e os Processos de desertificação. Revista Brasileira de Climatologia, v. 1, p. 7-14, 2005.

COSTA, A.C.; SOARES, A. Local spatiotemporal dynamics of a simple aridity index a region susceptible to desertification. Journal of Arid Environments, v. 87, p. 8-18, 2012.

COSTA, M.S.; LIMA, K.C.; ANDRADE, M.M.; GONÇALVES, W.A. Tendências observadas em extremos de precipitação sobre a região Semiárida do Nordeste do Brasil. Revista Brasileira de Geografia Física, v. 08, n. 5, p. 1321-1334, 2015.

DELGADO, D.B.M.; CARVALHO, M. Potencial da energia solar fotovoltaica em geração distribuída para manutenção da pegada de carbono do mix elétrico brasileiro. In: Congresso Brasileiro de Gestão Ambiental e Sustentabilidade, João Pessoa, 2016.

EASTERLING, D.R.; HORTON, B.; JONES, P.D.; PETERSON, T.C.; KARL, T.R.; PARKER, D.E.; SALINGER, M.J.; RAZUVAYEV, V.; PLUMMER, N.; JAMASON, P.; FOLLAND, C.K. Maximum and minimum temperature trends for the globe. Science, v. 277, n. 5324, p. 364-367, 1997.

EASTERLING, D.R. United States Historical Climatology Network Daily Temperature and Precipitation Data (1871-1997). ORNL Oak Ridge National Laboratory, 2002.

EPE - Empresa de Pesquisa Energética. Anuário Estatístico de Energia Elétrica 2014 - ano base 2013. 2014. Disponível em: $\quad \mathrm{http}: / / w w w . e p e . g o v \cdot b r / A n u a r i o E s t a t i s t i c o d e$ EnergiaEletrica/20130909_1.pdf. Acesso em: 12 ago. 2016.

FECHINE, J.A.L.; GALVÍNCIO, J.D. Aplicação do teste de Mann-Kendall na análise de tendências climáticas - bacia hidrográfica do rio Brigida - estado de Pernambuco. In: SEABRA, G.F.; SILVA, J.A.N.; MENDONÇA, I.T.L. (Organizadores). A conferência da Terra: aquecimento global, sociedade e biodiversidade. João Pessoa-PB: Editora Universitária da UFPB, 2010.

FOLHES, M.T.; FISCH, G. Caracterização climática e estudo de tendências nas séries temporais de temperatura do ar e precipitação em Taubaté (SP). Revista Ambiente e Água - An Interdisciplinary Journal of Applied Science, v. 1, n. 1, 2006.

FU, G.; YU, J.; YU, X.; OUYANG, R.; ZHANG, Y.; WANG, P.; LIU, W.; MIN, L. Temporal variation of extreme rainfall events in China, 1961-2009. Journal of Hydrology, v. 487, p. 48-59, 2013.

García-Garizábal, I.; ESPINOZA, C.C. FuCHSIA: Future Climate and Hydrological Scenarios for Environmental Management and Assessment. Statistical Climate Change Program, Guayaquil, 2016.

García-Garizábal, I.; Romero, P.; Jimenez, S.; Jordá, L. Evolución climática en la costa de Ecuador por efecto del cambio climático. DYNA, v. 84, n. 203, P. 37-44, 2017.

GOOSSENS, C.; BERGER, A. Annual and seasonal climatic variations over the northern hemisphere and Europe during the last century. In Annales geophysicae. Series B. Terrestrial and planetary physics, v. 4, n. 4, p. 385-399, 1986.

GROISMAN, P.Y.; EASTERLING, D.R. Variability and trends of total precipitation and snowfall over the United States and Canada. Journal of Climate, v. 7, n. 1, p. 184-205, 1994.

IBGE - Instituto Brasileiro de Geografia e Estatística. Atlas geográfico brasileiro. 2002. Disponível em: http://atlasescolar.ibge.gov.br/images/at- 
las/mapas_brasil/brasil_clima.pdf. Acesso em: 04 ago. 2016.

IPCC - Intergovernmental Panel on Climate Change. Climate change 2007: Climate change impacts, adaptation and vulnerability, IPCC Working Group II, $4^{\text {th }}$ Assessment Report.Sumary for Policymakers. Houghton, 2007.

KARL, T.R.; KNIGHT, R.W. Secular trends of precipitation amount, frequency, and intensity in the United States. Bulletin of the American Meteorological society, v. 79, n. 2, p. 231-241, 1998.

KENDALL, M.G. Rank Correlation Methods. London: Charles Griffin, 1975.

KHESHGI, H.S.; WHITE, B.S. Testing distributed parameter hypotheses for the detection of climate change. Journal of climate, v. 14, n. 16, p. 3464-3481, 2001.

LUCENA, A.F.P.; SZKLO, A.S.; SCHAEFFER, R.; SOUZA, R.R.; BORBA, B.S.M.C.; COSTA, I.V.L.; AMARO JÚNIOR, O.P.; CUNHA, S.H.F. The vulnerability of renewable energy to climate change in Brazil. Energy Policy, v. 37 , p. $879-889,2009$

LYRA, G.B.; OLIVEIRA-JÚNIOR, J.F.; ZERI, M. Cluster analysis applied to the spatial and temporal variability of monthly rainfall in Alagoas state, Northeast of Brazil. International Journal of Climatology, v. 34, n. 13, p. 3546-3558, 2014.

MANN, H.B. Nonparametric tests against trend. Econometric. The econometric society, v. 13, p. 245-259, 1945.

MARENGO, J.A. Condições climáticas e recursos hídricos no Norte Brasileiro. Clima e Recursos Hídricos no Brasil, Associação Brasileira de Recursos Hídricos FBMC/ANA, 2003.

MARENGO, J.A.; CAMARGO, C.C. Surface air temperature trends in Southern Brazil for 1960-2002. International Journal of climatology, v. 28, n. 7, p. 893-904, 2008.

MATSUYAMA, H.; MARENGO, J.A.; OBREGON, G.O.; NOBRE, C.A. Spatial and temporal variabilities of rainfall in tropical South America as derived from climate prediction center merged analysis of precipitation. International journal of climatology, v. 22, n. 2, p. 175-195, 2002.

MENDONÇA, F.; DANNI-OLIVEIRA, I.M. Climatologia: noções básicas e climas do Brasil. São Paulo: Oficina de Textos, 2007.

MINUZZI, R.B.; SEDIYAMA, G.C.; BARBOSA, E.D.M.; Melo Júnior, J.C.F.D. Climatologia do comportamento do período chuvoso da região sudeste do Brasil. Revista Brasileira de Meteorologia, v. 22, n. 3, p. 338-344, 2007.

MODARRES, R.; SILVA, V.DPR. Rainfall trends in arid and semi-arid regions of Iran. Journal of Arid Environments, v. 70, n. 2, p. 344-355, 2007.

MOLION, L.C.B.; BERNARDO, S.O. Uma Revisão da Dinâmica das chuvas no Nordeste Brasileiro. Revista Brasileira de Meteorologia, v. 17, n. 1, p. 1-10, 2002.

MORAES, J.M.; PELLEGRINO, G.Q.; BALLESTER, M.V.; MARTINELLI, L.A.; VICTORIA, R.L.; KRUSCHE, A.V. Trends in hydrological parameters of a southern Brazilian watershed and its relation to human induced changes. Water Resources Management, v. 12, n. 4, p. 295-311, 1998.

MOSCATI, M.C.L.; GAN, M.A. Rainfall variability in the rainy season of semiarid zone of Northeast Brazil (NEB) and its relation to wind regime. International Journal of Climatology, v. 27, n. 4, p. 493-512, 2007.
NAE - Núcleo de Assuntos Estratégicos da Presidência da República. Mudança de clima, v. 1: Negociações internacionais sobre a mudança de clima: vulnerabilidade, impactos e adaptação à mudança de clima. Cadernos NAE-SECOM. Brasília, 2005a.

NAE - Núcleo de Assuntos Estratégicos da Presidência da República. Mudança de clima, v. 2: Mercado de carbono. Cadernos NAE-SECOM. Brasília, 2005 b.

NOBRE, P. Mudanças climáticas e desertificação: os desafios para o Estado Brasileiro. In: LIMA, R.C.C.; CAVALCANTE, A.M.B.; PEREZ-MARIN, A.M. (Ed) Desertificação e mudanças climáticas no semiárido brasileiro. Campina Grande: INSA-PB, p. 25-36, 2011.

NOGUEIRA, G.M.F., GIRARD, O.R.S.; PAVAN, R.C.; SOARES, L.C.R. Eixos integrados de desenvolvimento da Paraíba: Uma visão estratégica para o Estado. SEPLAG: João Pessoa, 2014

OLIVEIRA, P.T.; LIMA, K.C. Linear trend of occurrence and intensity of heavy rainfall events on Northeast Brazil. Atmospheric Science Letters, v. 15, n. 3, p. 172-177, 2014.

PEDROZA, I.C.B. Estimativa da Climatologia Diária da Precipitação e Investigação de Possíveis Influências das Fases da Lua nas Chuvas no Estado da Paraíba. Dissertação, Universidade Federal de Campina Grande (UFCG), 2009.

PEIXOTO, I.M.B.M.; ABRAHãO, R. Mudanças climáticas e seus impactos no Nordeste brasileiro, Relatório Final PIBIC, 2015.

PINHEIRO, A.; GRACIANO, R.L.G.; SEVERO, D.L. Análise de tendência das séries temporais de precipitação da região sul do Brasil. Revista Brasileira de Meteorologia, v. 28, n. 3, p. 281-290, 2013.

RAMOS, R.P.L. Precipitation characteristics in the Northeast Brazil dry region. Journal of Geophysical Research, v. 80, n. 12, p. 1665-1678, 1975.

SALVIANO, M.F.; GROPPO, J.D.; PELLEGRINO, G.Q. Trends Analysis of Precipitation and Temperature Data in Brazil. Revista Brasileira de Meteorologia, v. 31, n. 1, p. 64-73, 2016.

SANTOS, E.B.; LUCIO, P.S. Precipitation regionalization of the Brazilian Amazon. Atmospheric Science Letters, v. 16, n. 3, p. 185-192, 2015.

SEN, P.K. Estimates of the regression coefficient based on Kendall's tau. Journal of the American Statistical Association, v. 63 , p. $1379-1389,1968$.

SILVA, V.D.P.R. On climate variability in Northeast of Brazil. Journal of Arid Environments, v. 58, n. 4, p. 575-596, 2004.

SNEYERS, R. On the use of Statistical Analysis for the Objective Determination of Climatic Change. Meteorologische Zeitschrift, v. 1, p. 247-256, 1992.

TEODORO, P.E.; Oliveira-Júnior, J.F., Cunha, E.R., Correa, C.C.G., Torres, F.E., Bacani, V.M., Gois, G.; Ribeiro, L.P. Cluster analysis applied to the spatial and temporal variability of monthly rainfall in Mato Grosso do Sul State, Brazil. Meteorology and Atmospheric Physics, v. 128, n. 2, p. 197-209, 2016.

This is an Open Access article distributed under the terms of the Creative Commons Attribution Non-Commercial License which permits unrestricted non-commercial use, distribution, and reproduction in any medium provided the original work is properly cited. 